\title{
Cough-Induced Spontaneous Rupture of the Kidney Secondary to Anticoagulant Therapy: Wunderlich's Syndrome
}

\author{
Antikoagülan Tedaviye Sekonder Öksürüğün Indüklediği Spontan Böbrek Rüptürü: \\ Wunderlich Sendromu
}

\author{
Kamil Fehmi Narter, Kubilay Sabuncu, Bilal Eryıldırım, Övünç Kavukoğlu, Kemal Sarıca \\ University of Health Sciences, Kartal Dr. Lütfi Kırdar Training and Research Hospital, Clinic of Urology, Istanbul, Turkiye
}

\begin{abstract}
Spontaneous renal or other organ ruptures secondary to anticoagulants have rarely been reported. The clinical features of renal rupture include acute flank/abdominal pain, haematuria, hypotension and shock. It can occur due to increased intraabdominal pressure during coughing. Rupture is most commonly caused by renal tumors such as angiomyolipomas. In the literature, other known causes are long-term haemodialysis, arteriosclerosis or arteritis. Wunderlich's syndrome is an extremely dangerous complication that may cause death if not treated intensively. If the haemorrhage is self-limiting and the patient is responsive to fluid replacement, the patient can be managed conservatively. Selective angiographic embolization and emergency nephrectomy (partial or total) are the treatment options. In the literature, we found only one case that was presented as spontaneous non-traumatic renal rupture associated with coughing. In our case, total nephrectomy had to be performed, but it was not adequate.
\end{abstract}

Keywords: Spontaneous renal rupture, cough, anticoagulant, Wunderlich's syndrome

Öz

Spontan böbrek veya diğer organ rüptürleri antikoagülanlara sekonder çok nadir bildirilmiştir. Klinik tabloda akut flank/karın ağrısı, hematüri, hipotansiyon ve şok görülebilir. Öksürük esnasında karın içi basıncının artışına bağlı oluşabilir. Rüptürün en sık sebebi anjiomyolipomlar gibi böbrek tümörleridir. Diğer sebepler arasında uzun süreli diyaliz, arteritler ve ateroskleroz sayılabilir. Eğer agresif tedavi edilmezse hayatı tehdit eden bir durumdur. Hemoraji kendini sınırlarsa konservatif yaklaşılabilir. Anjiyografik selektif embolizasyon ve parsiyel/total nefrektomi diğer tedavi seçenekleridir. Literatürde buna benzer bir olgu bildirilmiştir. Bizim olgumuzda takip sonrası total nefrektomi yapılsa da, bu yeterli olmamıştır.

Anahtar Kelimeler: Spontan böbrek rüptürü, öksürük, antikoagülan, Wunderlich sendromu

\section{Introduction}

Wunderlich's syndrome is a spontaneous non-traumatic bleeding confined to the subcapsular and/or perinephric spaces in patients with no known underlying cause and constitutes an emergency medical condition $(1,2)$. Various terms have been used including spontaneous perirenal haematoma, spontaneous subcapsular renal haemorrhage, nontraumatic perirenal haematoma and spontaneous perinephric haematoma. The etiology of spontaneous renal rupture has not been described yet. Possible causes include benign [e.g., angiomyolipomas
(AML), tuberous sclerosis, renal cyst, adenoma, lipoma, and hamartoma] and malignant (e.g., oncocytoma, renal clear cell carcinoma, and Wilms' tumor) tumors or it can occur secondary to vasculitis (polyarteritis nodosa), nephritis, blood dyscrasias (anticoagulant agents, polycythaemia), renal stone disease, arteriovenous malformations and fistulas, venous thrombosis or rupture of renal artery/intraparenchymal aneurysm $(3,4)$. Wunderlich's syndrome is clinically characterized by the "Lenk's triad" which includes acute flank pain, flank mass and hypovolemic shock. In this case report, we aimed to present and discuss a rare syndrome according to the literature.

Correspondence: Kamil Fehmi Narter MD, University of Health Sciences, Kartal Dr. Lütfi Kırdar Training and Research Hospital, Clinic of Urology, İstanbul, Turkiye

Phone: +90 5324153550 E-mail: fehminarter66@gmail.com ORCID ID: orcid.org/0000-0003-2057-0142

Received: 20.11.2016

Accepted: 18.02 .2017

Cite this article as: Narter KF, Sabuncu K, Eryıldırım B, Kavukoğlu Ö, Sarıca K. Cough-Induced Spontaneous Rupture of the Kidney Secondary to Anticoagulant Therapy: Wunderlich's Syndrome. J Urol Surg 2017;4:211-214. 


\section{Case Presentation}

This case is a 41-year-old male who was admitted to the emergency room (ER) with weakness, changes in urine color, nausea and mild abdominal pain after a coughing episode on going through the last few days. There was not any trauma history. His physical examination elicited a solid mass palpated on the left flank region. The patient had mild pallor, his pulse was normal, pulse rate was $88 / \mathrm{min}$, blood pressure was $110 / 70$ $\mathrm{mmHg}$, respiratory rate was $22 / \mathrm{min}$, and body temperature was $36.8^{\circ} \mathrm{C}$. However, on the examination there was not any tenderness in the abdomen. In his medical history, there were acute rheumatic fever, atrial and mitral valve regurgitation and cerebrovascular occlusive disease. Moreover, he had been using some medications, namely warfarin (1 mg $1 \times 1 /$ oral daily), and metoprolol succinate ( $25 \mathrm{mg} 1 \times 1 /$ oral daily). In our case, he had hypertension in his medical history, and had not undergone any operation. Abnormal values in the first laboratory analysis were serum glucose $155 \mathrm{mg} / \mathrm{dL}$, total bilirubin $1.98 \mathrm{mg} / \mathrm{dL}$, direct

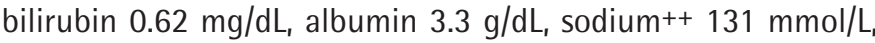

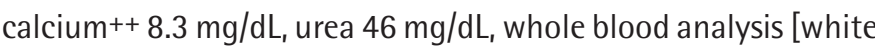
blood cell 12.1 103/uL, hemoglobin ( $\mathrm{Hgb}) 11.3 \mathrm{~g} / \mathrm{dL}$, hematocrit (Htc) 34.1\%, platelets 239 103/uL], and coagulation tests [prothrombin time (PT) $29.7 \mathrm{sec}$, activated partial thromboplastin time (APTT) $39.7 \mathrm{sec}, \mathrm{PT} \%$ \%27, international normalized ratio (INR) 2.9]. Macroscopic hematuria was seen in the urine sample and then microscopic urine examination confirmed that during the ER stay. After the initial evaluation, he was hospitalized in the urology department because of decrease in the blood test values ( $\mathrm{Hgb}$ and $\mathrm{Htc}$ ) and hematoma around the kidney. Informed consent was obtained from the patient. On the first contrast-enhanced computed tomography (CT) of the abdomen, there was grade IV renal injury and retroperitoneal hematoma on the left side (Figure 1). During the first 3 days, the patient

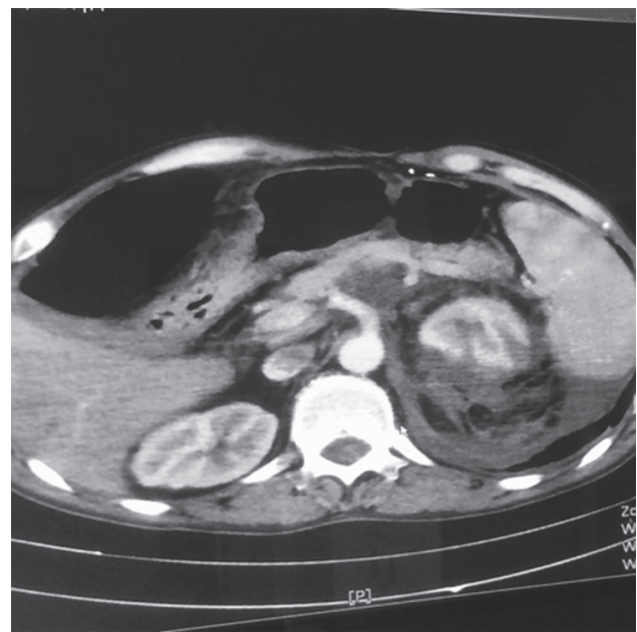

Figure 1. First computed tomography abdomen scan with contrast, there was grade 4 renal injury and retroperitoneal hematoma on the left side according to the American Association for the Surgery of Trauma classification was closely followed up conservatively. At this period, the oral anticoagulant agent was stopped. Daily whole blood count and coagulation tests were obtained. After being clinically stable for a two-day period, control abdominal CT revealed expanding retroperitoneal hematoma (Figure 2). Blood count and coagulation tests values reached the dangerous level ( $\mathrm{Htc}$ 20.1\% minimum $-34 \%$ maximum, PT $24.5 \mathrm{sec}$. minimum -49.5 sec. maximum, APTT 35.6 sec. minimum -180 sec. maximum, PT (\%) 15\% minimum -35\% maximum, INR 2.19 minimum -5.59 maximum) in this hemodynamically unstable period. Selective angioembolization was tried but it was not successful. Lastly, patients' clinical status had gone worse and emergency radical

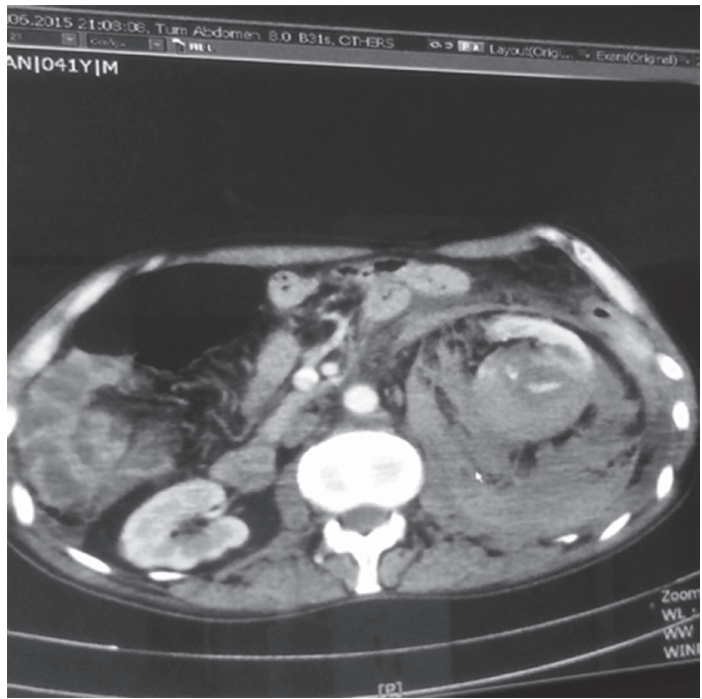

Figure 2. During the conservative approach, there was enlarged retroperitoneal hematoma on the preoperatively computed tomography abdomen scan with contrast

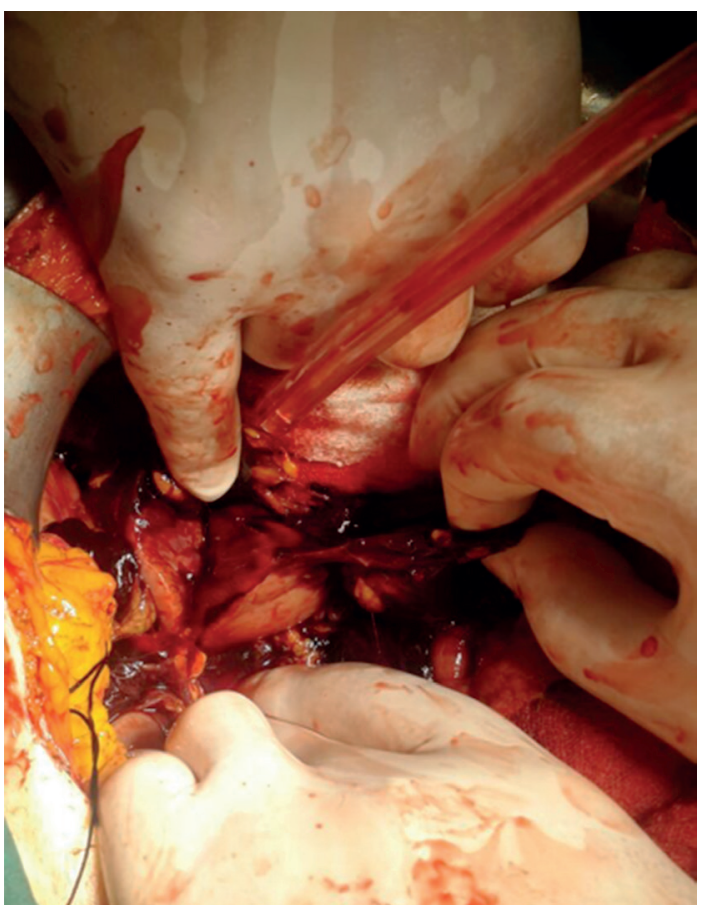

Figure 3. Peroperatively view, laceration on the lower pole of left kidney 
nephrectomy operation was preferred at the fourth day for the protection of the vital findings. At the time of operation, a lower pole laceration was found on the left kidney and total nephrectomy was performed (Figure 3,4 ). All along this period, 4 units of whole blood and 2 units of red cell transfusions were made. Postoperatively, the patient was transferred to the intensive care unit. During the two days in this unit, new clinical progressive mortal condition has evolved. Despite all the aggressive treatment attempts, the patient died. According to the pathology report, pathological material did not involve any tumor as an AML or other pathologies like aneurysm in the kidney specimen and the report declared only lower pole renal rupture on the left side.

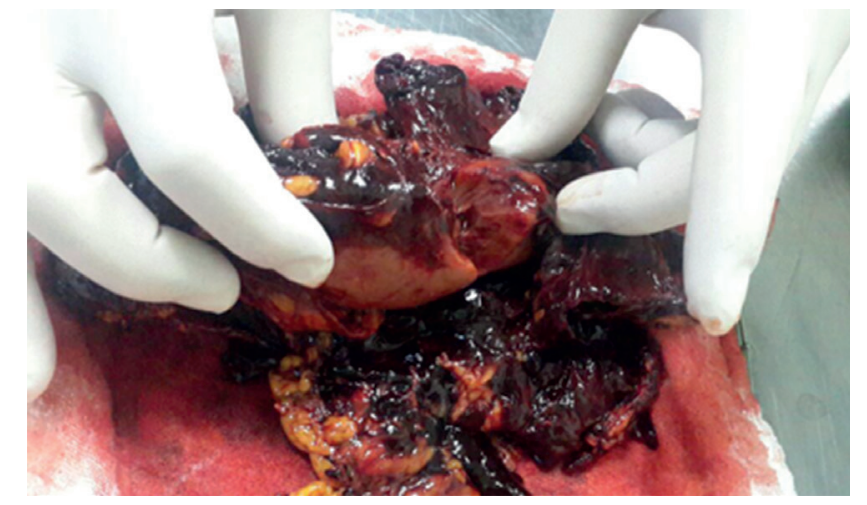

Figure 4. Postoperatively macroscopic view, about $3 \mathrm{~cm}$ laceration on the lower pole of left kidney

\section{Discussion}

Most of the urological surgeons may not be used to this terminology. In the literature, we could just find extremely rare case reports about this syndrome. On the other hand, HerlynWerner-Wunderlich syndrome is a different condition that is characterized by a triad of type 3 Müllerian duct anomaly, obstructed hemivagina and mesonephric duct anomalies (including congenital renal anomalies) (5). These two different terms can be easily confused.

Spontaneous organ or tissue ruptures secondary to anticoagulant therapy occurring in arteries, veins, spleen, pancreas, and kidneys have been reported in the literature $(6,7,8,9,10)$, however, the etiopathogenesis is not clear yet. At the molecular level during the tissue-coagulation process many molecules like tissue factor are important. A reasonable mechanism has been suggested that an unrecognized minor trauma initiates hematuria, which continues due to depletion of the clotting factors. As we well know, bleeding is the most frequent adverse effect of anticoagulant therapy in somewhere. The incidence of major bleeding in patients under oral anticoagulant therapy is $0.5 \%-1.6 \%$ in per year. In addition, antiplatelet or fibrinolytic treatment increases the risk of bleeding (8). One of the most common locations for anticoagulant-related bleeding is the urinary tract $(15 \%)$. The retroperitoneum is a rare location for spontaneous bleeding (1\%) (8). However, retroperitoneal hemorrhage is a serious complication of anticoagulant therapy that may cause significant mortality.

The majority of patients with this syndrome are managed conservatively but very close follow-up is a necessity. If there is any suspicion about this unstable, hemodynamically serious condition, you may have to choose an aggressive emergency treatment modality. The patient is usually discharged with a transient mild hematuria caused by an intraparenchymal microaneurysm which may be easily misdiagnosed thus can be a life-threatening problem. Predisposing factors for spontaneous renal ruptures are congenital malformations of the kidney, smoking, hypertension, atherosclerosis, pregnancy, minor traumas (coughing episode), recent surgical operation, malignancy, renal angiomyolipoma, radiation, and/or anticoagulant therapy, and cyclophosphamide usage $(6,7,8,9,10)$. Rupture is the most dangerous result and the risk depends on age, gender, histology, and size of the laceration. Diagnosis of the spontaneous renal rupture is not easy. Hematuria can be microscopic or gross and hemodynamic instability may occur in a rupture $(6,7)$. A pioneer symptom that could help the diagnosis of a spontaneous renal rupture is the deterioration of the condition of patient with an increase in the intra-abdominal pressure (during defecation or coughing) as in our case. In patients who have non-traumatic acute flank or abdominal pain, it is important to determine whether the patient has been taking anticoagulation medication due to bleeding diathesis or not. If an emergency laparotomy is not necessary, we recommend that these cases should be treated surgically after clinical stabilization. Kidney ruptures are the main reason for haematomas and the patients need a proper balance between coagulation mechanisms and anticoagulation. Endovascular surgery (selective transcatheter arterial embolization) is considered to be an option for the management of this syndrome. In our case, the rupture caused a life-threatening hemorrhage and hypovolemic shock. Therefore, we performed a definitive diagnostic operation as open exploratory laparotomy, and subsequently, a radical nephrectomy was the only option but it was not adequate. Early laparotomy at the time of admission might be a good option for patients with macroscopic hematuria or grade 4 renal trauma (laceration to the lower pole of the kidney), however, close follow-up is also a preferred option nowadays. Especially, partial/total nephrectomy or kidney repair can be better than conservative management or endovascular treatment (selective angiographic embolization) for grade 4 renal trauma as for grade 5 cases.

\section{Ethics}

Informed Consent: Consent form was filled out by all participants. 
Peer-review: Externally peer-reviewed.

\section{Authorship Contributions}

Surgical and Medical Practices: K.F.N., Concept: K.F.N., Design: K.S., Data Collection or Processing: Ö.K., Analysis or Interpretation: B.E., Literature Search: K.F.N., Writing: K.S.

Conflict of Interest: No conflict of interest was declared by the authors.

Financial Disclosure: The authors declared that this study received no financial support.

\section{References}

1. Ahmad M, Arora M, Reddu R, Rizvi I. Wunderlich's syndrome (spontaneous renal haemorrhage). BMJ Case Rep 2012:2012.

2. Anastasiou I, Katafigiotis I, Pournaras C, Fragkiadis E, Leotsakos I, Mitropoulos D, Constantinides C. A Cough deteriorating gross hematuria: A clinical sign of a forthcoming life-threatening rupture of an intraparenchymal aneurysm of renal artery (Wunderlich's Syndrome). Case Reports in Vascular Medicine 2013:452317.
3. Seseke S, Schreiber M, Rebmann U, Seseke F. Spontaneous perirenal hematomas in patients taking anticoagulation medication or having a bleeding diathesis. Aktuelle Urol 2008;39:215-218.

4. Koo V, Duggan B, Lennon G. Spontaneous rupture of kidney with peri-renal haematoma: a conservative approach. Ulster Med J 2004;73:53-56.

5. Nagy V, Nagyova D, Szabo GZ. Spontaneous bleeding from the kidneys to the retroperitoneum (Wunderlich-syndrome). Egészségtudományi Közlemények, 4. kötet, 1. szám 2014, pp. 42-47.

6. Hibner RW. Spontaneous rupture of the kidney with massive hemorrhage. A complication of anticoagulation. Am J Surg 1969;118:637-640.

7. Luna I, Leadbetter RL, Gilbert DR. Spontaneous rupture of the kidney: A complication of anticoagulation-report of 2 cases. J Urol 1973;109:788789.

8. Kim YH, Kim CK, Park CB, Jeon HW, Moon MH, Choi SY. Spontaneous rupture of internal iliac artery secondary to anticoagulant therapy. Ann Thorac Cardiovasc Surg 2013;19:228-230.

9. Tarrass $F$, Benjelloun M, Medkouri G, Hachim K, Gharbi MB, Ramdani B. Spontaneous kidney rupture--an unusual complication of Wegener'sgranulomatosis. Nephrol Dial Transplant 2007;22:280.

10. Mitchell C, Riley CA, Vahid B. Unusual complication of heparin induced thrombocytopenia after mitral valve surgery: Spontaneous rupture of spleen. Ann Thorac Surg 2007;83:1172-1174. 